\title{
Experience of LGBT+ Employees at the Workplace in India: Diversity and Inclusion
}

\author{
Abhay Mane \\ Independent researcher \\ Maharashtra, India \\ E-mail: drabhay86@yahoo.com
}

Received: July 3, 2021 Accepted: August 4, $2021 \quad$ Published: August 10, 2021

doi:10.5296/ijssr.v9i2.18925 URL: https://doi.org/10.5296/ijssr.v9i2.18925

\begin{abstract}
Introduction: Not many individuals belonging to lesbian, gay, bisexual and transgender $(\mathrm{LGBT}+)$ community are open about their identity in society or at their workplace. There is scarcity of data on LGBT+ employees at workplace in India with very few employers encouraging active hiring of the community or considering having policies in place for these individuals.

Objective: The objective of this study is to understand the current situation of LGBT+ employees in India and find out about their experiences related to their sexuality.

Methods: A survey of 10 questions was conducted and answered by LGBT+ individuals who are employees and currently work in India. The employees of any type of organization were allowed to take the survey. The questionnaire probed into various aspects of their experience at the workplace.

Results: 103 individuals answered the survey. Only 17 (16.50\%) responders are completely open about their orientation whereas 6 are partially open. 8 survey takers reported to have faced negativity after opening about their sexuality at the workplace whereas 16 out of 23 have faced some form of discrimination. Only 18 survey takers said that they wish to come out to their colleagues in near future.

Conclusion: Very few LGBT+ employees are open about their sexuality at the workplace. Discrimination and harassment are likely to happen to these individuals. Hence, there is a need for protective laws for LGBT employees.
\end{abstract}

Keywords: LGBT+, workplace, sexuality, discrimination 


\section{Introduction}

From ancient to modern times, homosexuality in India has been a subject of discussion. Although Hindu texts and scriptures have always mentioned homosexuality since ancient times, the same is still considered as a taboo in modern India. As far as legal rights are concerned, on 6 September 2018, a 5-judge constitutional bench of Supreme Court of India invalidated part of Section 377 of the Indian Penal Code, hence making homosexuality legal in India. In striking down the colonial-era law that made gay sex punishable by up to 10 years in prison, one judge said the landmark decision would "pave the way for a better future (DNA, 2018)."

Despite these positive changes in the legal rights of LGBT+ individuals in India, homophobia is prevalent in India (Bedi, 2011). Any form of sexuality is rarely discussed in public and therefore discussion about alternative sexuality is all the more rare. India is among countries with a social element of a third gender. Mental, physical, emotional and economic violence against the LGBT community in India continues to be a problem (DNA India, 2013). This attitude towards alternate sexuality is going through slow progression and we have also seen more representation of homosexuality in Indian media and cinema.

There is no way to ascertain the exact number of LGBT+ individuals in India. Coming to acceptance of LGBT+ individuals at workplace almost no data is available on experiences of the community in the same. And given that most of the members of LGBT+ community are 'closeted' it's challenging to generate such data. This small study was designed to gain insights into lives and experiences of LGBT + individuals at the workplace and might pave a way for future research. The objective of this study is to understand the situation of LGBT+ employees in India and find out about their experiences related to their sexuality.

\section{Methods}

A survey of 10 questions was designed and was supposed to be answered only by individuals who belong to LGBT+ community and who are employees in India. The survey was completely anonymous. The first question asked responders about their gender and it was optional. The second question was about the type of organization they work for. The third question in the survey asked about their 'openness' at the workplace. In an attempt to have a closer look at the situation, the fourth question was about the type of colleagues who know about the sexual orientation of the responders. The fifth question probed into the immediate experience of this 'coming out' at the workplace. Trying to understand the work life of the responders better, the sixth question was about the discrimination they have faced, if any at the workplace. The seventh question asked about the form of this discrimination, if any. The options given for this question included denial of promotion, denial of opportunities and substandard increments. Other than this kind of discrimination, the eighth question probed into any type of harassment faced by responders at the workplace. The next question tried to understand the form of harassment, if any, experienced by the responders. The tenth and the last question asked whether responders have any plans of 'coming out' about their sexuality at the workplace. For a detailed description of each question along with answer choices please refer to Annexure. 


\section{Macrothink}

\section{Results}

Total of 103 responders answered the survey.

1) The first question yielded the following response. Out of 103 responders, 77 were male, 16 were female and 6 were transgender individuals. 4 survey takers did not wish specify their gender.

Table 1. Response to the question 'Please mention your gender'

\begin{tabular}{ll}
\hline Answer & No. of Responses \\
\hline a. male & 77 \\
b. female & 16 \\
c. transgender & 6 \\
d. transsexual & 0 \\
e. non-binary & 0 \\
f. gender fluid & 0 \\
g. Other & 0 \\
h. don't wish to specify & 4 \\
Total & 103 \\
\hline
\end{tabular}

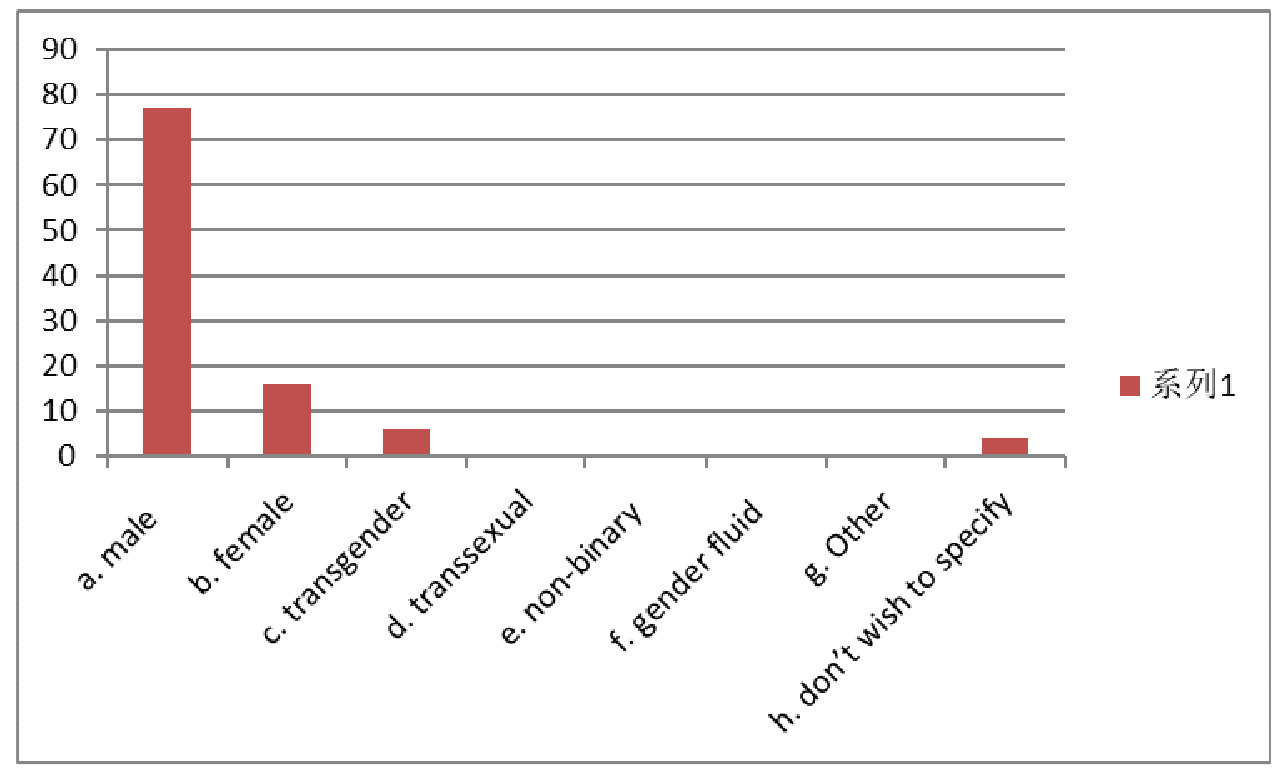

Figure 1.

2) The 103 survey takers work for different types of organizations with most of them working for corporate sector $(59.22 \%)$, followed by NGO (12.62\%), educational institutions $(10.67 \%)$, government sector (8.74\%). 8 individuals selected 'others' as an option. 
Table 2. Response to the question 'Please mark the type of organization you work for'

\begin{tabular}{ll}
\hline Type of Organizations & No. of Responses \\
\hline a. Corporate & 61 \\
b. NGO & 13 \\
c. Educational institution & 11 \\
d. Government sector & 9 \\
e. Others & 9 \\
Total & 103 \\
\hline
\end{tabular}

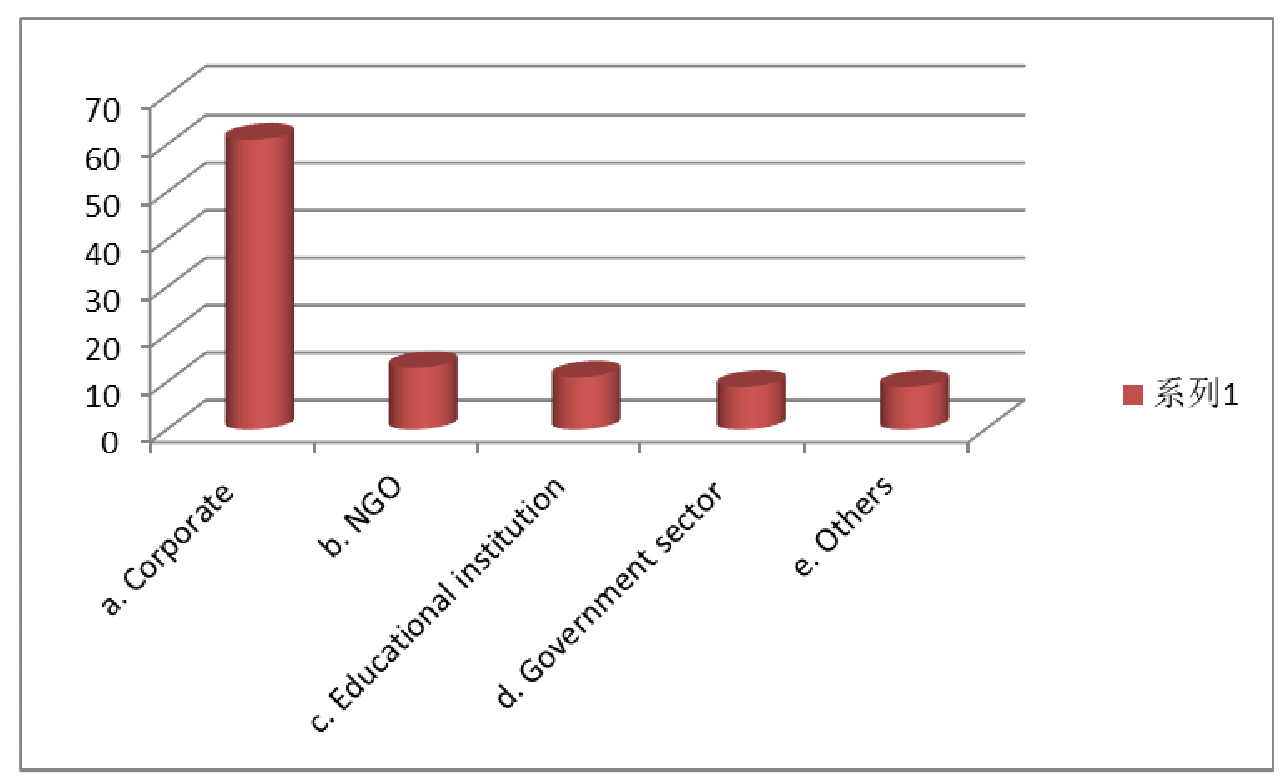

Figure 2.

3) Only $17(16.5 \%)$ responders out of 103 are completely open about their sexual orientation at the workplace. 6 individuals are partially open about their sexuality. In total, 23 (22.33\%) out of 103 responders are open in some way about their sexual orientation.

Table 3. Response to the question 'Are you open about your sexual orientation at the workplace?'

\begin{tabular}{ll}
\hline Answer & No. of Responses \\
\hline a. yes & 17 \\
b. no & 80 \\
c. partially & 6 \\
Total & 103 \\
\hline
\end{tabular}




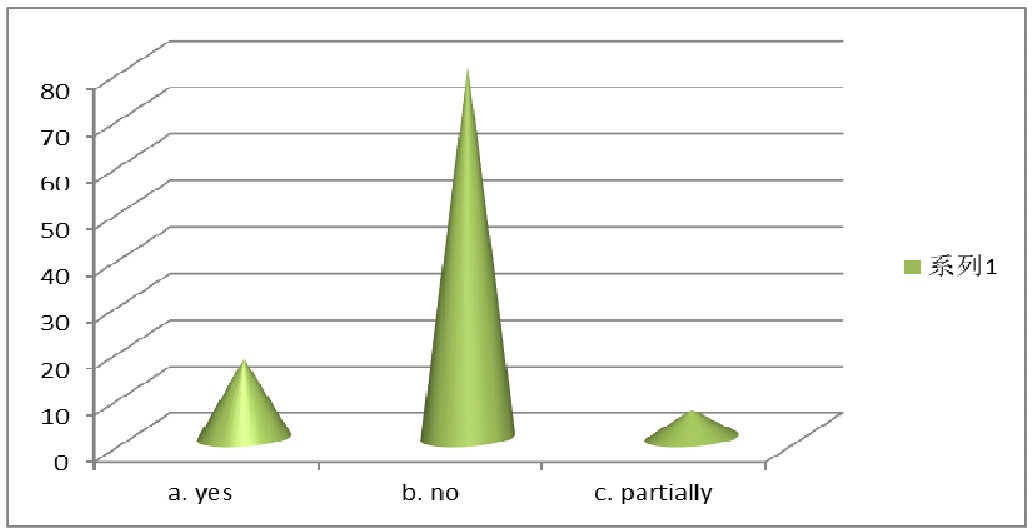

Figure 3.

4) Only 6 responders are out of the closet to their respective managers whereas only 5 are open to human resources department. 14 responders reported that they are open about their sexuality to 'other' colleagues. As this question allowed multiple answers, there was some overlap in terms of types of colleagues.

Table 4. Response to the question 'What type of colleagues know about your sexual orientation?' (multiple option selection available)

\begin{tabular}{ll}
\hline Answer & No. of Responses \\
\hline a. Human resources dept & 5 \\
b. Manager & 6 \\
c. Other colleagues/co-workers & 14 \\
d. N/A & 80 \\
Total & 105 \\
\hline
\end{tabular}

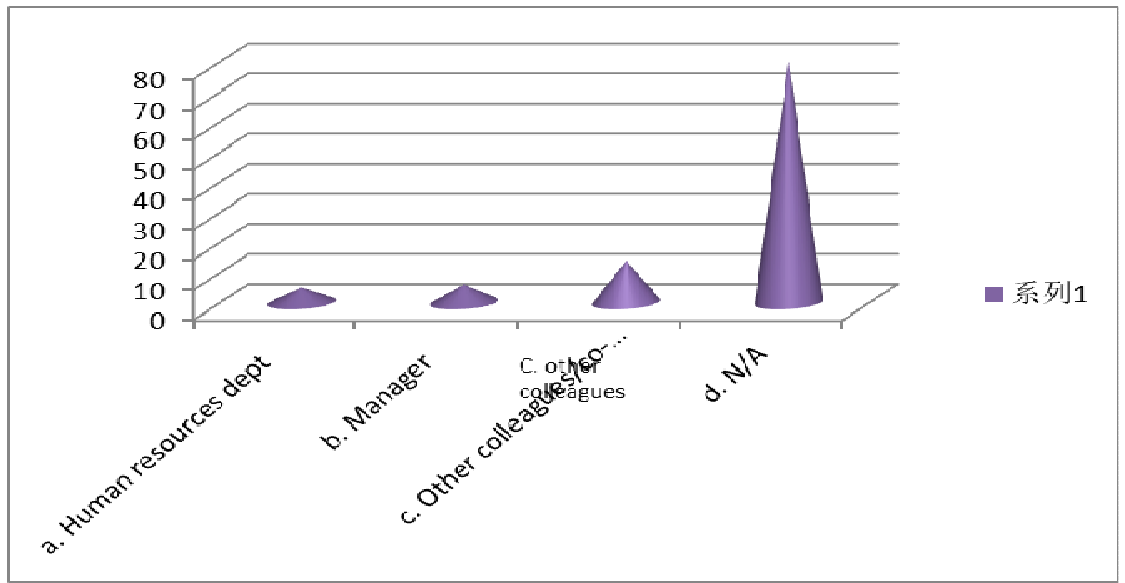

Figure 4. 


\section{Macrothink}

5) Out of 23 individuals who open about their sexuality, only 3 (13.04\%) individual reported that their 'coming out' was received very well. $5(21.73 \%)$ individuals reported that their 'coming out' was received fairly well whereas 7 (30.43\%) responders said that their 'coming out' was received 'okay'. Out of $23,8(34.78 \%)$ responders reported that they faced negativity.

Table 5. Response to the question 'How well was your coming out received?'

\begin{tabular}{ll}
\hline Answer & No. of Responses \\
\hline a. Very well & 3 \\
b. Fairly well & 5 \\
c. okay & 7 \\
d. Faced negativity & 8 \\
e. N/A & 80 \\
Total & 103 \\
\hline
\end{tabular}

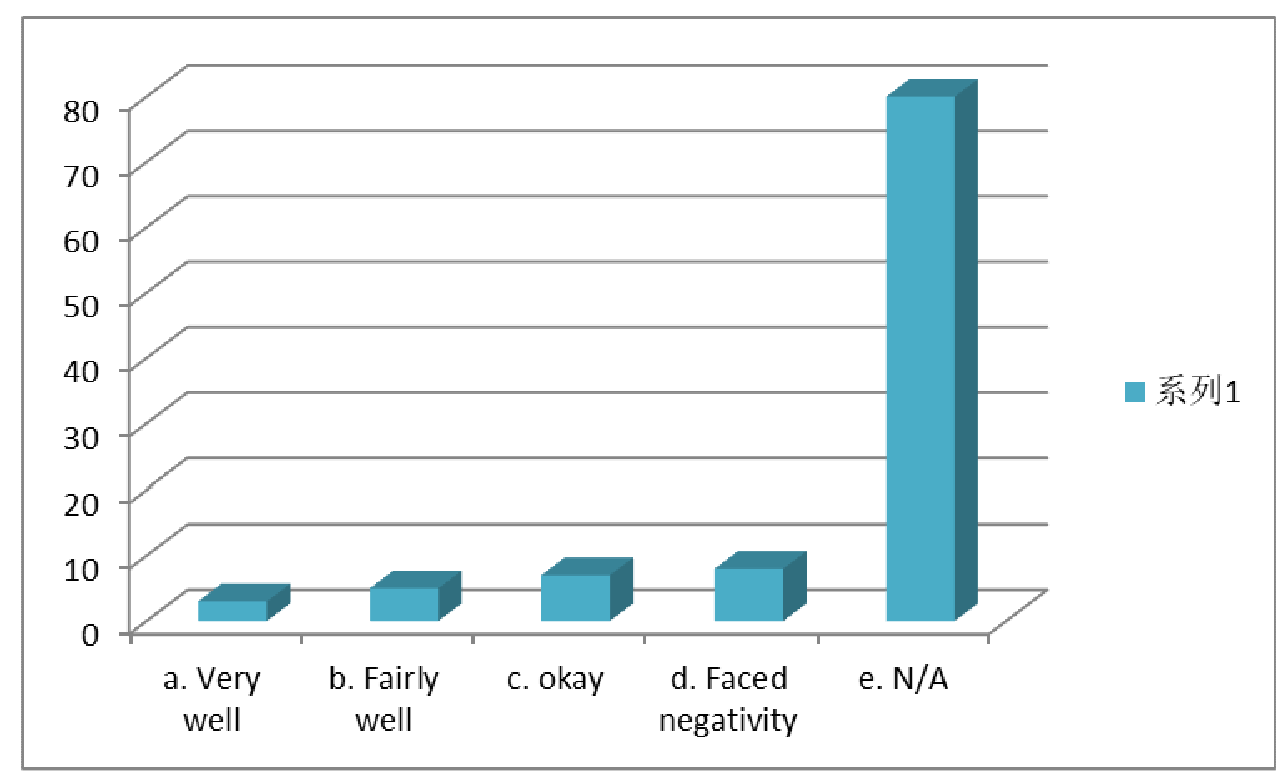

Figure 5.

6) Out of 23 individuals who are out at their workplace $16(69.56 \%)$ have faced some kind of discrimination. 


\section{Macrothink}

International Journal of Social Science Research

ISSN 2327-5510

2021, Vol. 9, No. 2

Table 6. Response to the question 'Have you faced any discrimination at your workplace because of your sexuality?'

\begin{tabular}{ll}
\hline Answer & No. of Responses \\
\hline a. Yes & 16 \\
b. No & 7 \\
c. N/A & 80 \\
Total & 103 \\
\hline
\end{tabular}

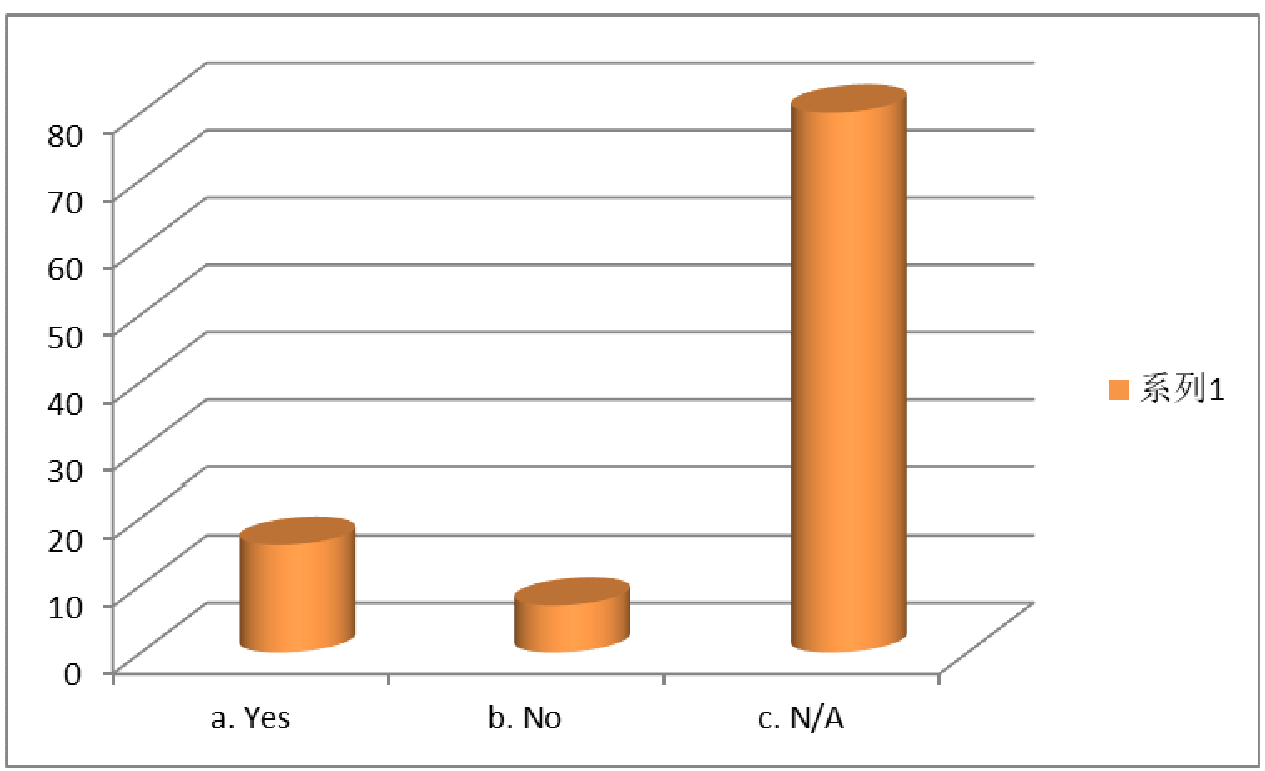

Figure 6.

7) Six individuals reported that they were denied opportunities because of their sexual orientation. 4 said that they were denied promotions whereas 6 reported of receiving substandard increments.

Table 7. Response to the question 'What was the form of this discrimination?'

\begin{tabular}{ll}
\hline Answer & No. of Responses \\
\hline a. Denied opportunities & 6 \\
b. Denied promotions & 4 \\
c. Substandard increments & 6 \\
d. None & 7 \\
f. N/A & 80 \\
Total & 103 \\
\hline
\end{tabular}




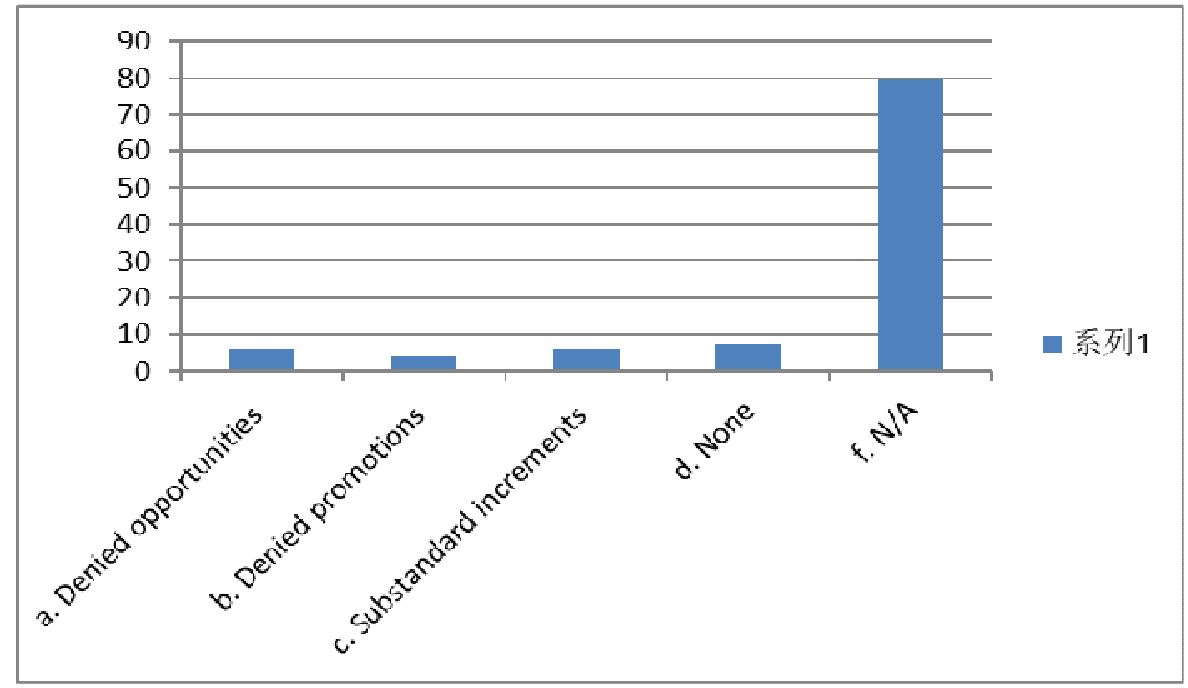

Figure 7.

8) Twelve $(52.17 \%)$ out of 23 responders who are out at their workplace reported of having faced harassment.

Table 8. Response to the question 'Have you faced any harassment at the workplace?'

\begin{tabular}{ll}
\hline Answer & No. of Responses \\
\hline a. Yes & 12 \\
b. No & 11 \\
d. N/A & 80 \\
Total & 103 \\
\hline
\end{tabular}

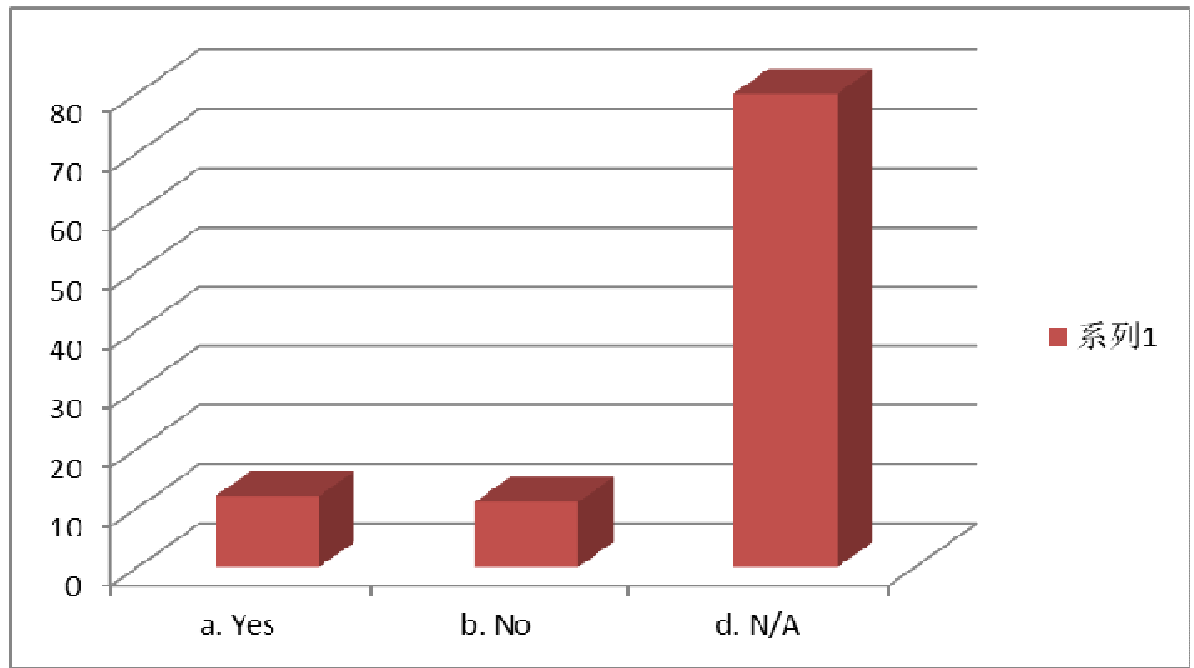

Figure 8. 


\section{Macrothink}

9) Seven responders reported that they were excluded from the groups of colleagues. 4 individuals said that they faced verbal abuse/offensive remarks at the workplace. Only 1 survey taker reported of experiencing physical abuse. No individuals out of responders has faced sexual harassment at the workplace.

Table 9. Response to the question 'How would you describe this harassment?'

\begin{tabular}{ll}
\hline Type of harassment & Number of Responses \\
\hline a. Exclusion of groups & 7 \\
b. Verbal abuse/offensive remarks & 4 \\
c. Physical abuse & 1 \\
d. Sexual harassment & 0 \\
e. None & 11 \\
f. N/A & 80 \\
Total & 103 \\
\hline
\end{tabular}

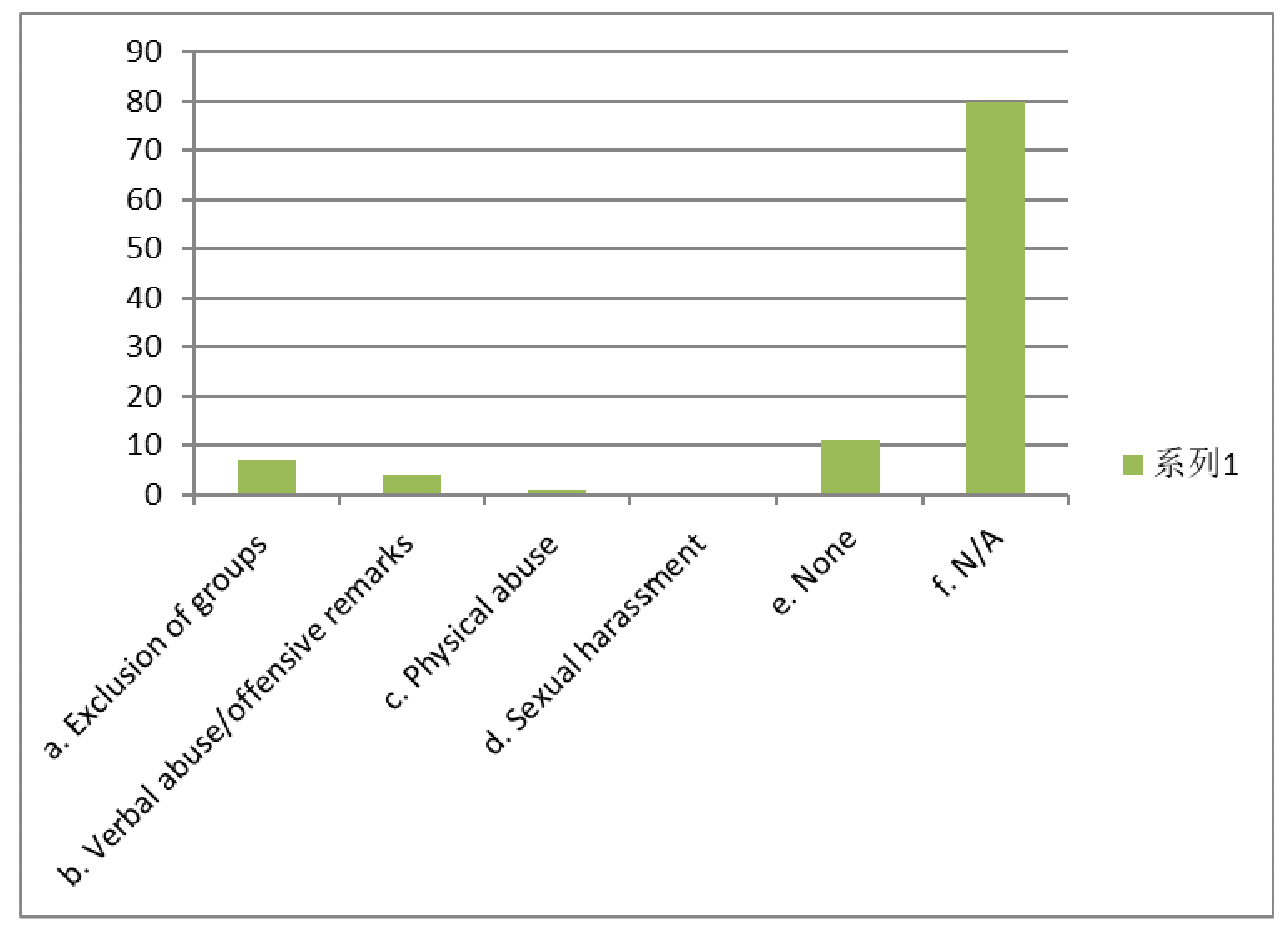

Figure 9.

10) Eighteen (22.5\%) out of 80 (who aren't open at the workplace) individuals said that they plan of coming out in near future. 27 answered this question as 'maybe' whereas 35 individuals don't have any such intention. 


\section{Macrothink}

Table 10. Response to the question 'If you are NOT open at your workplace do you intend to do so in near future?'

\begin{tabular}{ll}
\hline Answer & No. of Responses \\
\hline a. Yes & 18 \\
b. No & 35 \\
c. Maybe & 27 \\
d. N/A & 23 \\
Total & 103 \\
\hline
\end{tabular}

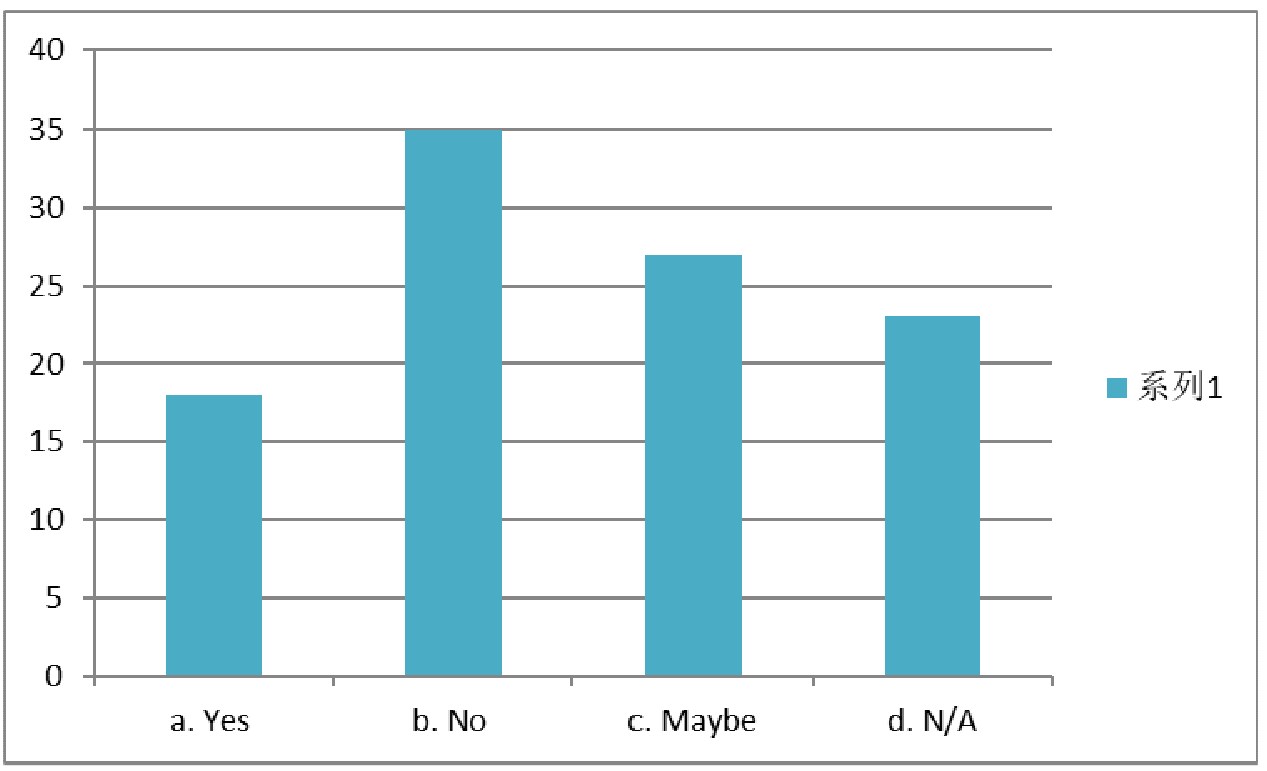

Figure 10.

\section{Discussion}

Our study throws light on few very important aspects of Indian workplaces. The most of the LGBT+ employees who answered the survey are men. The representation of transgender individuals in Indian workforce is still miniscule. Our most $(59.22 \%)$ of the responders belong to corporate sector with some representation of NGOs, government sector and educational institutions. Only $22.33 \%$ individuals being out of the closet is a grim number for any workforce. Most of the individuals out these are open to colleagues other than human resources (HR) and/or their managers. This highlights an important point. Not being open to HR and/or manager only emphasizes the fact that LGBT+ employees are unsure about the official stand the organization would take.

Although the number of individuals who are out of closet is very small (23), 34.78\% of them reporting to have faced negativity at the time of coming out isn't a positive sign. More than $2 / 3$ rds $(72.72 \%)$ have faced some form discrimination after they came out at the workplace. This percentage is high and should not be overlooked. The form of discrimination ranges 
from substandard increments to denial of promotions. Despite having limited number of responders who are out of closet the discrimination is evident at most of the workplaces.

Harassment is one more challenging issue for LGBT+ employees. More than 2/3rds $(69.56 \%)$ of the responders who are out of the closet report that they have faced some sort of harassment at the workplace. Exclusion from the groups of colleagues and offensive/homophobic remarks are common forms of the harassment. Only one individual reported physical abuse. The answers to these questions reveal the situation of most the LGBT+ employees who are out of the closet. Very few individuals have an intention to come out at the workplace in near future. This maybe because of negative experiences of the fellow colleagues or due to the feeling of insecurity. In both cases this reflects badly on the work culture which possibly has minimum tolerance/acceptance of alternate sexualities.

There is scarcity of data on LGBT+ individuals' experiences at the workplace in India. One study conducted by mission for Indian gay \& lesbian empowerment (MINGLE) reports similar results to that of our study. Only $25 \%$ individuals are out to their colleagues in this study as compared to $22.33 \%$ in our study (Mission for Indian Gay \& Lesbian Empowerment, 2016).

In the same study by MINGLE, 40\% individuals have reported some kind of harassment and $20 \%$ individuals have faced discrimination from their own manager/HR. Two thirds of individuals reported having faced homophobic comments at the workplace. This study, however, also probes into resources such as protective policies which employers have to offer. It also tries to understand how satisfied/unsatisfied LGBT+ employees are towards their respective employers. ${ }^{4}$

LGBT+ employees who are out of the closet can significantly add to productivity of the organization. Needless to say, those employees who are out contribute to the diversity of the workplace with different viewpoints, ideas, suggestions etc. Our study not only gives voice to LGBT+ employees but also makes an attempt to understand the current attitude of Indian workplaces towards LBGT+ employees.

Our study has few limitations. First is the small sample size. It was a herculean task to reach out to LGBT+ employees in India. This speaks volume about the 'openness' about sexual orientation at the workplace or even in general in society. We did not ask responders about the names of the organizations they are associated with. This was done consciously as to make responders feel safe and completely anonymous.

To conclude, this study throws light on experience of LGBT+ employees at workplace in India. Our study is one of its kinds and paves the way for future research in this field. The current picture at the Indian workplace is not very positive. However, with a recent ruling from Supreme Court decriminalizing consensual homosexual sex between adults has come as a silver lining. This change in the legal standing will most probably reflect not only in society but also in Indian workforce. Going forward, hopefully, LGBT+ employees will feel safer in their workplace and employers will take necessary measures to protect every employee. In studies to follow, we would like to understand perspective of employers/HR professionals on 


\section{Macrothink \\ International Journal of Social Science Research \\ ISSN 2327-5510 2021, Vol. 9, No. 2}

this.

This is an independent study and there are no financial conflicts of interest to disclose.

\section{Appendix A}

The link to the survey. Retrieved from https://s.surveyplanet.com/bZFxJXxnD

\section{References}

Bedi, R. (2011). Homophobia persists in India despite court reforms. The Telegraph (UK). London.

DNA. (2018). SC decriminalises gay sex, but J\&K LGBTs will have to wait longer.

DNA India. (2013). Violence against LGBT groups still prevails in India. 24 November 2013

Mission for Indian Gay \& Lesbian Empowerment. (2016). The Indian LGBT Workplace Climate Survey 2016. Retrieved April 30, 2021, from https://vartagensex.org/wp-content/uploads/2019/10/1559396942000-mingle-lgbt-wrkplc-cli mt-srvy-2016.pdf

\section{Copyrights}

Copyright for this article is retained by the author(s), with first publication rights granted to the journal.

This is an open-access article distributed under the terms and conditions of the Creative Commons Attribution license (http://creativecommons.org/licenses/by/4.0/). 